\title{
運動量理論を用いた超音速流れでの揚・抗力値予測*1 \\ Lift and Drag Prediction in Supersonic Region Based on Momentum Conservation Theory
}

\author{
山 崎 渉*2 楠 瀬 一 洋*3,*4 ·松島 紀 佐*2 ${ }^{* 2}$ 橋 和 博*2 \\ Wataru Yamazaki, Kazuhiro Kusunose, Kisa Matsushima and Kazuhiro NaKahashi
}

Key Words : Aerodynamic Characteristics, Lift and Drag Prediction, Supersonic Flow, Momentum Conservation Theory, CFD

\begin{abstract}
Recently, as advanced drag prediction method in transonic region, a drag decomposition method is watched with keen interest. This method is based on and extended from the momentum conservation theory on the closed integral surface around the airplane, which is usually called 'Control Volume Method' (CVM). In this paper, aiming the next target which is the drag decomposition in supersonic flows, the validation study of the CVM in the supersonic region was conducted. Two dimensional structured mesh computation of NACA0012 airfoil was used for the investigation. At the lift and drag prediction using the CVM in the supersonic region, the discontinuous variation or oscillation of the lift and drag value was observed when the integral surface was set to some particular positions related to the generated shock waves. By the avoidance of the inappropriate positions, however, the good performance of the lift and drag prediction using CVM was achieved.
\end{abstract}$$
\text { 主 な 記 号 }
$$$$
\text { A.o.A : 迎角 }
$$$$
C_{\mathrm{d}}: \text { 抗力係数 }
$$$$
C_{1}: \text { 揚力係数 }
$$$$
D \text { : 抗力 }
$$$$
\overrightarrow{\vec{I}}: \text { 単位テンソル }
$$$$
J_{\mathrm{cv}}: \boldsymbol{S}_{\mathrm{far}} \text { を決定する物体上流側の index }
$$$$
L: \text { 揚力 }
$$$$
L_{\mathrm{cv}}: \boldsymbol{S}_{\mathrm{far}} \text { を決定する後流側の index }
$$$$
M: \text { マッ八数 }
$$$$
\overrightarrow{\boldsymbol{n}}=\left(n_{x}, n_{y}, n_{z}\right): \text { 外向き単位法線ベクトル }
$$$$
p: \text { 圧力 }
$$$$
R e: \text { レイノルズ数 }
$$$$
S_{\text {body }} \text { : 物体表面 }
$$$$
S_{\mathrm{far}} \text { ：物体を囲む任意の閉曲面 }
$$$$
\boldsymbol{S}_{\text {shock }} \text { : 任意の衝撃波面 }
$$$$
\overrightarrow{\boldsymbol{u}}=\left(u_{x}, u_{y}, u_{z}\right): \text { 速度ベクトル }
$$$$
\mu: \text { 粘性係数 }
$$$$
\rho: \text { 密度 }
$$$$
\overrightarrow{\vec{\tau}}=\left(\vec{\tau}_{x}, \vec{\tau}_{y}, \vec{\tau}_{z}\right)^{\mathrm{T}}: \text { 粘性応カテンソル }
$$$$
(\quad)_{\infty} \text { : 一樣流物理量 }
$$$$
()_{x, y, z}: \text { 主流方向を } x \text { 方向とする直交座標系 }
$$$$
\text { *1 (C) } 2006 \text { 日本航空宇宙学会 }
$$$$
\text { 平成 } 17 \text { 年 } 7 \text { 月 } 28 \text { 日原稿受理 }
$$$$
\text { *2 東北大学大学院工学研究科航空宇宙工学専攻 }
$$$$
* 3 \text { 東北大学流体科学研究所 }
$$$$
* 4 \text { 現防衛庁技術研究本部第三研究所 }
$$

1. は じ めに

航空機の空力性能を決定する最も重要なパラメータとして 巡航状態, 一般には遷音速域での揚・抗力係数值があげられ る.この遷音速域での揚·抗力值を計算し，実験值との比較を 行う AIAA Drag Prediction Workshop II が 2003 年に開 催されている.近年 CFD (Computational Fluid Dynamics）は著しい進歩を遂げたが, Drag Prediction Workshop の開催からも分かるように航空機の巡航状態における誤差 $1 \%$ 程度の精度良い揚・抗力値予測は未だ注目の高い研究課 題である1).

近年，遷音速領域における抵抗值予測においては，抵抗 要素分解手法 ${ }^{2 \sim 6)}$ が注目を浴びている.これは, 抵抗值を発 生原因別に分類する手法であり, 実験 ${ }^{2)} \cdot \mathrm{CFD}^{3 \sim 6)}$ の両面か ら研究がなされている.航空機の高度な設計を行う上では 欠かせない技術であり，CFDにおいては数值拡散効果に基 づく非物理的な抵抗要素を除去できるという特性も併せ持 つことから，特に注目されている.上記の Drag Prediction Workshop II においても光の適用事例か報告されている31 . この抵抗要素分解手法においては, 物体を囲む任意の閉曲 面内での運動量保存の関係を基にした抵抗予測手法 (Control Volume Method，CVM) を兴の基礎式に据えている. しかし，CVM の基礎式は理論的には証明され，既に実験 での適用例は見られるものの ${ }^{2)}$, CFD における実用的な精 度としての検証事例はほとんど報告されていないのか現状 である．また，これまでに超音速流れにおける抵抗要素分 解はなされていない．空間遠方場にも衝撃波が存在しうる
} 
超音速流れにおいて抵抗要素分解を行う上では，兰の基礎 式である CVM の検証が不可避である . 近年 , 超音速航空 機の空力的可能性を探る研究が再び注目を集めている7 10) ことからも，超音速流れにおける CVM の精度検証は光の 先の目標である, 超音速流れでの抵抗要素分解を可能にす る上で極めて重要であると言える

そこで本論文では，超音速流れ場において CVMにより 揚・抗力値を算出し，弚の精度・妥当性を検証することを 目的としている．具体的には，弚の物体遠方場に設定する 積分面の位置依存性に関しての検証を行う . 一般にCVM が用いられる際, 弚の粘性項の効果は無視されがちである が，本研究では光の効果についても吟味する．また比較検 証のため，遷音速流れ場での CVM による揚・抗力值予測 も併せて行った 。

\section{CVM 理 論}

2.1 表面積分法 一般に用いられている抵抗予測手法 として, 物体の表面で圧力と粘性応カテンソルを面積分す る表面積分法があげられる .

$$
D=\iiint_{\boldsymbol{S}_{\text {body }}}\left[-\left(p-p_{\infty}\right) n_{x}+\vec{\tau}_{x} \cdot \vec{n}\right] \mathrm{d} s
$$

第 1 項が圧力抵抗に，第 2 項が表面摩擦抵抗に相当し, 単 位法線ベクトル $\vec{n}$ は物体から見て外向きのベクトルである .

$2.2 \mathrm{CVM}$ 一般的な CVM 理論は既に多数の文献に乥 の導出が示されていることから，ここでは翼の前・後縁から 衝撃波が発生している典型的な超音速流れ場のケースにおい て产の導出を示す．弚の流れ場の模式图を第 1 图に示した . ここで衝撃波により分割される各領域を $\boldsymbol{V}_{i}(i=1, \ldots, 4)$ とした .この時, 定常流を仮定すると各領域内で運動量が 保存されるので，

$$
\iiint_{\boldsymbol{V}_{i}} \operatorname{div}(\overrightarrow{\boldsymbol{F}}) \mathrm{d} v=0 \quad(i=1, \ldots, 4)
$$

が成立する .ここで $\overrightarrow{\boldsymbol{F}}$ は，

$$
\overrightarrow{\boldsymbol{F}}=-\rho \overrightarrow{\boldsymbol{u}} \overrightarrow{\boldsymbol{u}}-\left(p-p_{\infty}\right) \overrightarrow{\overrightarrow{\boldsymbol{I}}}+\overrightarrow{\vec{\tau}}
$$

で表現される.$(2)$ 式にガウスの発散定理を施し，面積分 形式で表現すると，

$$
\iint_{\boldsymbol{S}_{i}} \overrightarrow{\boldsymbol{F}} \cdot \overrightarrow{\boldsymbol{n}} \mathrm{d} s=0 \quad(i=1, \ldots, 4)
$$

ここで，

$$
\begin{aligned}
& \boldsymbol{S}_{1}=\boldsymbol{S}_{\boldsymbol{F} 1}+\boldsymbol{S}_{\boldsymbol{B} 1}+\boldsymbol{S}_{\boldsymbol{w} 1 \boldsymbol{u}}+\boldsymbol{S}_{\boldsymbol{w} 2 \boldsymbol{u}} \\
& \boldsymbol{S}_{2}=\boldsymbol{S}_{\boldsymbol{F} 2}+\boldsymbol{S}_{\boldsymbol{B} 2}+\boldsymbol{S}_{\boldsymbol{w} 1 \boldsymbol{d}}+\boldsymbol{S}_{\boldsymbol{w} 3 u} \\
& \boldsymbol{S}_{3}=\boldsymbol{S}_{\boldsymbol{F} 3}+\boldsymbol{S}_{\boldsymbol{B} 3}+\boldsymbol{S}_{\boldsymbol{w} 2 \boldsymbol{d}}+\boldsymbol{S}_{\boldsymbol{w} 4 u} \\
& \boldsymbol{S}_{4}=\boldsymbol{S}_{\boldsymbol{F} 4}+\boldsymbol{S}_{\boldsymbol{B} 4}+\boldsymbol{S}_{\boldsymbol{w} 3 \boldsymbol{d}}+\boldsymbol{S}_{\boldsymbol{w} 4 \boldsymbol{d}}
\end{aligned}
$$

であり，各表面の定義は第 2 図に図示した . 単位法線べク トル $\overrightarrow{\boldsymbol{n}}$ は積分領域内から見て外向きのベクトルである．な

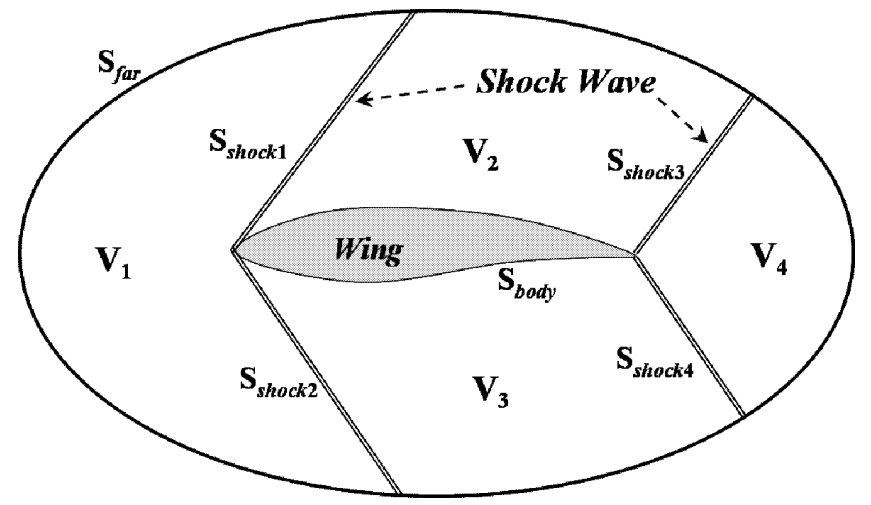

第1図 CVM のための流れ場模式図 (1)

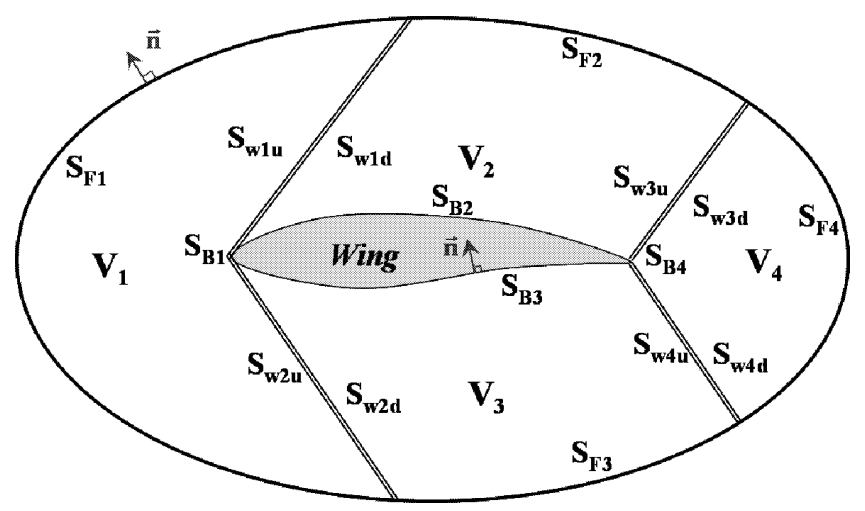

第 2 図 CVM のための流れ場模式図 (2)

おトポロジー的に当然，

$$
\begin{aligned}
& \boldsymbol{S}_{\mathrm{body}}=\boldsymbol{S}_{\boldsymbol{B} 1}+\boldsymbol{S}_{B 2}+\boldsymbol{S}_{\boldsymbol{B} 3}+\boldsymbol{S}_{\boldsymbol{B} 4} \\
& \boldsymbol{S}_{\mathrm{far}}=\boldsymbol{S}_{\boldsymbol{F} 1}+\boldsymbol{S}_{\boldsymbol{F} 2}+\boldsymbol{S}_{\boldsymbol{F} 3}+\boldsymbol{S}_{\boldsymbol{F} 4} \\
& \boldsymbol{S}_{\text {shock }(i)}=\boldsymbol{S}_{\boldsymbol{w}(i) \boldsymbol{u}}+\boldsymbol{S}_{\boldsymbol{w}(i) \boldsymbol{d}}
\end{aligned}
$$

が成立している．この時 (4) 式より

$$
\begin{aligned}
0= & \sum_{i=1}^{4} \iint_{\boldsymbol{S}_{i}} \overrightarrow{\boldsymbol{F}} \cdot \overrightarrow{\boldsymbol{n}} \mathrm{d} s \\
= & \iint_{\boldsymbol{S}_{\mathrm{far}}} \overrightarrow{\boldsymbol{F}} \cdot \overrightarrow{\boldsymbol{n}} \mathrm{d} s+\iint_{\boldsymbol{S}_{\text {body }}} \overrightarrow{\boldsymbol{F}} \cdot \overrightarrow{\boldsymbol{n}} \mathrm{d} s \\
& +\sum_{i=1}^{4}\left(\underset{\boldsymbol{S}_{\text {shock }(i)}}{\iint_{\boldsymbol{F}}} \cdot \overrightarrow{\boldsymbol{n}} \mathrm{d} s\right)
\end{aligned}
$$

であり，また衝撃波前後で運動量が保存されることを考慮 すると，

$$
\iint_{\boldsymbol{S}_{\text {shock }(i)}} \overrightarrow{\boldsymbol{F}} \cdot \overrightarrow{\boldsymbol{n}} \mathrm{d} s=0
$$

が成立する・よって (5)，(6) 式を用いることで，

$$
\iint_{\boldsymbol{S}_{\mathrm{far}}} \overrightarrow{\boldsymbol{F}} \cdot \overrightarrow{\boldsymbol{n}} \mathrm{d} s=\iint_{\boldsymbol{S}_{\text {body }}} \overrightarrow{\boldsymbol{F}} \cdot(-\overrightarrow{\boldsymbol{n}}) \mathrm{d} s=\text { Body Force }
$$


と物体に働く力を CVM 形式で表現できる．今，主流方向 を $x$ 方向，主流に対し鉛直上向き方向を $z$ 方向とすると，

$$
\begin{aligned}
& L=\iint_{\boldsymbol{S}_{\mathrm{far}}}\left(-\rho u_{z} \overrightarrow{\boldsymbol{u}}-\left(p-p_{\infty}\right) \vec{k}+\vec{\tau}_{z}\right) \overrightarrow{\boldsymbol{n}} \mathrm{d} s \\
& D=\iint_{\boldsymbol{S}_{\mathrm{far}}}\left(-\rho u_{x} \overrightarrow{\boldsymbol{u}}-\left(p-p_{\infty}\right) \vec{i}+\vec{\tau}_{x}\right) \overrightarrow{\boldsymbol{n}} \mathrm{d} s
\end{aligned}
$$

により揚・抗力值は表現されることとなる．結局，遠方場 に衝擊波が存在する超音速流れの場合でも，従来知られて いる街撃波を考慮していない場合の CVM 予測式と同一で あることが確認できる．また $\overrightarrow{\vec{\tau}}$ は以下の式で評価される．

$$
\begin{aligned}
\overrightarrow{\vec{\tau}} & =\left(\begin{array}{ccc}
\tau_{11} & \tau_{12} & \tau_{13} \\
\tau_{21} & \tau_{22} & \tau_{23} \\
\tau_{31} & \tau_{32} & \tau_{33}
\end{array}\right) \\
& =\tau_{i j} \\
& =\lambda \frac{\partial u_{l}}{\partial x_{l}} \delta_{i j}+\mu\left(\frac{\partial u_{i}}{\partial x_{j}}+\frac{\partial u_{j}}{\partial x_{i}}\right)
\end{aligned}
$$

ここで $\delta_{i j}$ は Kronecker のデルタであり,$\lambda$ は Stokes の仮 説を基に以下のように評価する .

$$
\lambda=-\frac{2}{3} \mu
$$

\section{3. 計算手法·条件}

本研究では上記の CVM による抵抗予測手法を 2 次元構 造格子計算結果に適用し検証する.支配方程式に薄層近似 Navier-Stokes 方程式を用い, 格子トポロジーは C 型格子 である. 粘性項に 2 次精度中心差分を，対流項には 3 次精 度 MUSCL 法で高次精度化した TVD 差分を用いる . また 時間積分には LU-SGS 陰解法を用い11)，乱流モデルには Baldwin-Lomax の代数モデル ${ }^{12)}$ を適用した . 外部境界条 件は Riemann 境界条件を用い，全面乱流を仮定している

計算対象としては NACA0012 翼型を用いる . 計算格子 は翼周り（ $j$ 方向）に $J_{\max }=303$ 点（翼面上に 201 点）， 翼から離れる方向 $(l$ 方向 $)$ に $L_{\max }=131$ 点とし, 最小 格子幅を $0.001 / \sqrt{R e}$ ，外部境界長を 30 倍としたものを主 に用いる.計算条件は，遷音速のケースとして $M_{\infty}=0.7$ ， A.o. $A=2.5 \mathrm{deg}, R e=9 \times 10^{6}$, 超音速のケースとして $M_{\infty}=2.0$, A.o. $A=2.0 \mathrm{deg}, R e=9 \times 10^{6}$ を主に用い 検証を行う.これら遷・超音速条件での客観的な流れ場可 視化結果として，弚の空間圧力分布を第 3 図に示した。

物体を囲む任意の閉曲面 $\boldsymbol{S}_{\mathrm{far}}$ は C 型格子の格子トポロ ジーを利用して第 4 图に示すように定義する .すなわち， $\boldsymbol{S}_{\mathrm{far}}$ は $l=L_{\mathrm{cv}}$ の面 $\boldsymbol{S}_{\mathrm{L}}$ と $j=J_{\mathrm{cv}}\left(と J_{\mathrm{max}}+1-J_{\mathrm{cv}}\right)$ の 面 $\boldsymbol{S}_{\mathrm{J}}$ とで表現される $. L_{\mathrm{cv}}=1,131$ が光れ光れ翼面上·外 部遠方境界に相当し， $J_{\mathrm{cv}}=1$ （と 303）, 52（と 252）が光

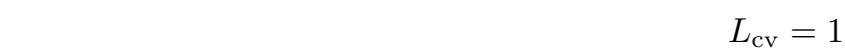
の時 (翼面上) は, $S_{\mathrm{J}}$ 面が存在せず，後流領域の $S_{\mathrm{L}}$ では

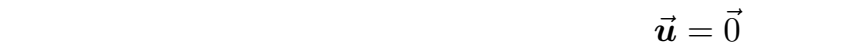
ことから，(8)，(9) 式が物体面上で圧力と粘性応力テンソ

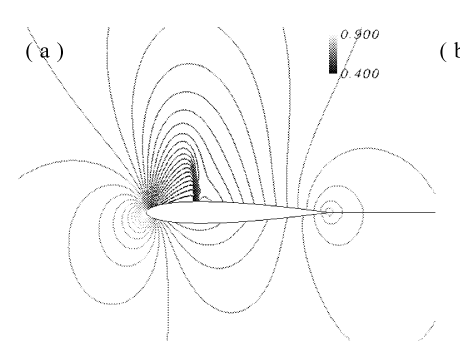

( b )

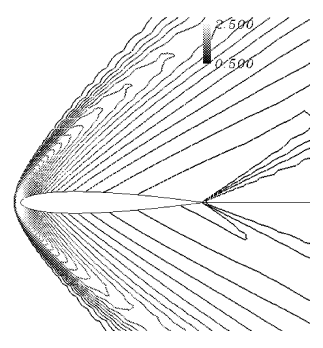

第 3 図 空間圧力分布図

(a) 遷音速条件，(b) 超音速条件

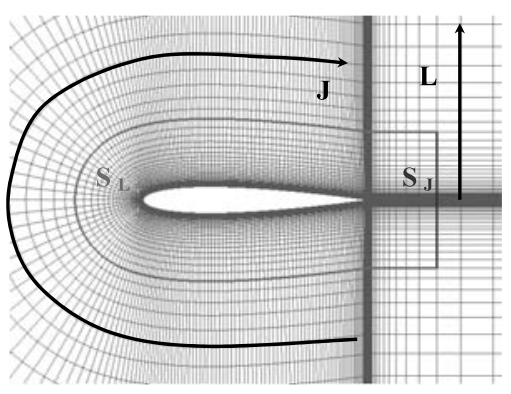

第 4 图 積分閉曲面定義

ルを積分する (1) 式に示したような表面積分法による力導 出に帰着することが分かる . 粘性応カテンソルに含まれる 微分項は 2 次精度中心差分て評価した。

\section{4. 検証および考察}

(1)式の表面積分手法により求まる揚·抗力値と，(8)，(9) 式の CVM により求まる揚・抗力値とを比較することによ り検証を進める . (7) 式から理解できるように，両者は理 論的には一致するはずであるので, 一意に求まる (1) 式の 値を $\mathrm{CFD}$ 計算結果としての基準値とし，積分面位置によ り変動する (8), (9) 式の值との比較を基に議論を進める .

$4.1 L_{\mathrm{cv}}$ 依存性 本節では CVMにより予測される揚・ 抗力値の $L_{\mathrm{cv}}$ 依存性について検証する.$J_{\mathrm{cv}}$ については， $J_{\mathrm{cv}}=5$ (物体下流遠方, Case-A) と $J_{\mathrm{cv}}=50$ (物体下流 近傍, Case-B) の位置に固定し, $L_{\mathrm{cv}}$ を 1 (物体表面) 130 (外部境界近傍) まて変化させて検証を行った . Case-A，B の $\boldsymbol{S}_{\mathrm{J}}$ 面と，代表的な $L_{\mathrm{cv}}$ の位置を第 5 図に示した . 遷 · 超音速の各ケースでの揚・抗力係数值の $L_{\mathrm{cv}}$ 依存性を第 6 , 7 図に示す．なお，表面積分により得られた揚・抗力值は 図中央 $\left(L_{\mathrm{cv}}=70\right)$ に図示した .

遷音速における揚力値予測においては，Case-A，B 共 に $L_{\mathrm{cv}}$ によらず表面積分值との良い一致が確認できる. $L_{\mathrm{cv}}=130$ 付近に振動が見られるが, 表面積分值に対し $0.5 \%$ 程度の变化であり，外部境界条件に依存するものであ ると推測される . 抗力值予測においては , 物体近傍に $\boldsymbol{S}_{\mathrm{J}}$ を 取った Case-B ではすべての $L_{\mathrm{cv}}$ に対して良い一致が見ら れたものの，物体遠方に設定された Case-A では $L_{\mathrm{cv}}=70$ 付近に $7 \%\left(8 \mathrm{ct}, 1 \mathrm{ct}=1 \times 10^{-4}\right)$ 程度の差が見られる。 また , これらの図においては，(8)，(9) 式より光の粘性応 

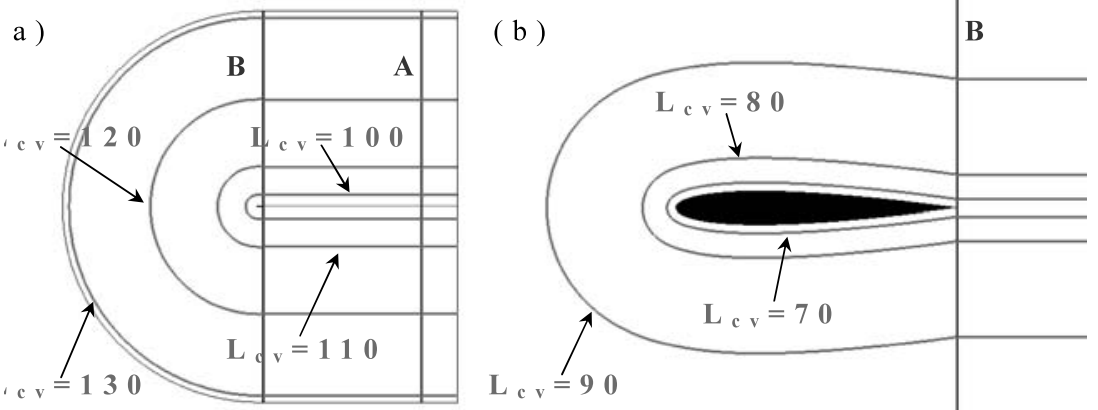

第 5 図 代表的な積分面位置の可視化図

(a) 全体図 , (b) 翼近傍図
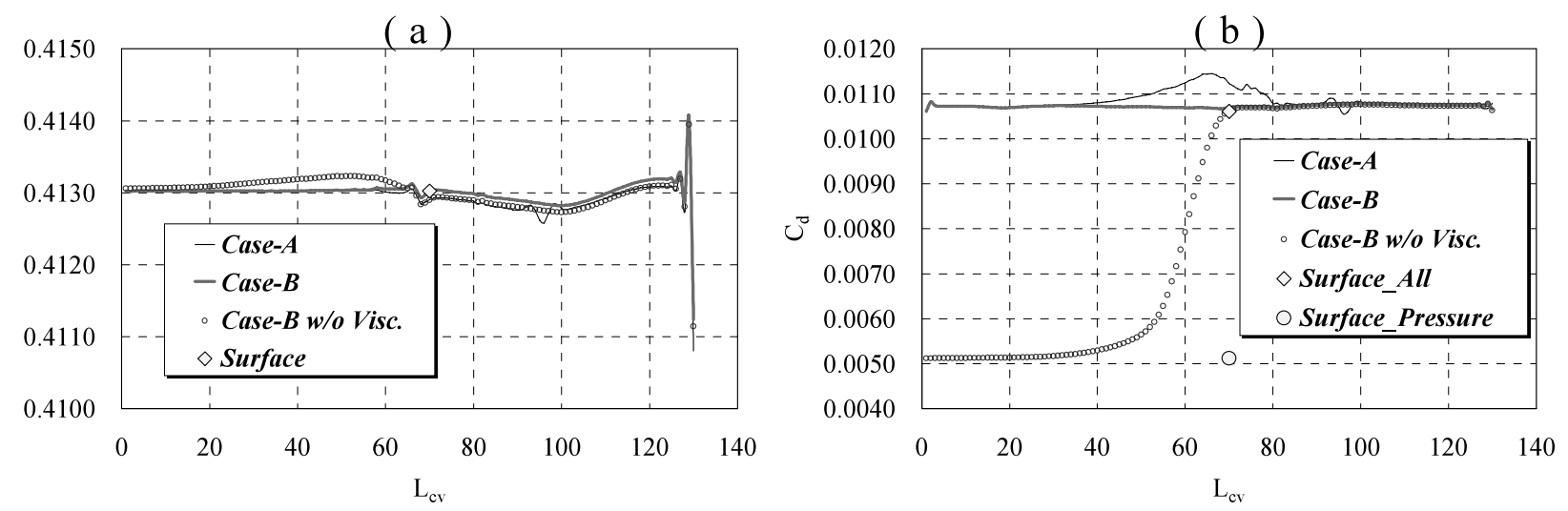

第 6 図 遷音速計算での $L_{\mathrm{cv}}$ 依存性

(a) 揚力値予測 ，(b) 抗力値予測
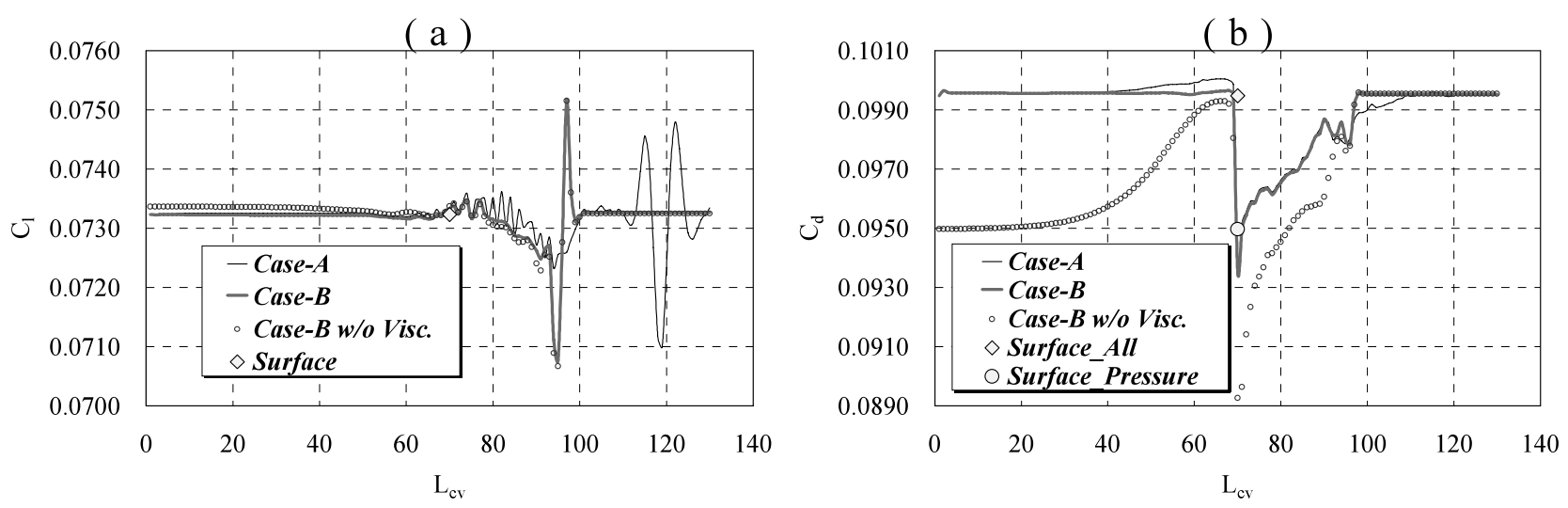

第 7 図 超音速計算での $L_{\mathrm{cv}}$ 依存性

(a) 揚力値予測 , (b) 抗力値予測

力項を省いた場合の Case-B の結果も “Case-B w/o Visc." として加えて示した .この場合, 物体近傍では予測抵抗値 が圧力抵抗值に一致し, 境界層近傍から離れるに従って全 抵抗值に漸近していることが確認できる。

超音速における揚力値予測においては, 両ケース共に物体 近傍では表面積分值に一致するものの，遠方場に最大 $4 \%$ 程 度の振動か認められる . 抗力值予測においても, 両ケース 共に $L_{\mathrm{cv}}=70$ 付近に最大 $6 \%(60 \mathrm{ct})$ 程度の強い不連続性 が認められる、第 8 図に, Case-B で振動や不連続か確認
された $L_{\mathrm{cv}}=70 ， 95$ の位置を圧力分布上に示した . 前者 は $S_{\mathrm{L}}$ が前縁上流の離脱衝撃波に接する位置であり，後者 は $S_{\mathrm{L}}$ と $S_{\mathrm{J}}$ の接合部周辺に衝撃波が位置する特異な条件 であることが分かる.すなわち超音速条件における揚・抗 力値の振動・不連続性は離脱衝撃波の影響によるものであ ることか理解できる．

$4.2 J_{\mathbf{c v}}-\boldsymbol{L}_{\mathrm{cv}}$ 依存性 本節では, 更なる詳細な CVM の位置依存性を解析することを目指し， $J_{\mathrm{cv}} \cdot L_{\mathrm{cv}}$ 両者の 依存性を検証する． $J_{\mathrm{cv}} \cdot L_{\mathrm{cv}}$ を弚れ光れ変化させた時の， 
CVM による揚・抗力值と乥の表面積分値との差の絶対值 を $J_{\mathrm{cv}}-L_{\mathrm{cv}}$ 空間に可視化した図を第 9,10 図に示す.

遷音速条件においては， 4.1 節で確認したとおり，揚力値 では外部境界付近 $\left(L_{\mathrm{cv}} \sim 130\right)$ において差か認められ，抗 力値では物体下流遠方場 $\left(J_{\mathrm{cv}} \sim 10\right)$ での $L_{\mathrm{cv}}=70$ 付近で 差か認められる . 揚力値に関しては外部境界条件の影響で あると考えられる．抗力值に関しては， $L$ 方向に格子サイ ズが急激に变化することによる数值拡散効果の積み重ねや 後流内の収束性に起因したものではないかと思われる . 全 体的には，十分な精度で抵抗值予測がなされていることが 確認できる。

超音速条件においては，4.1 節で確認したとおり，衝撃 波の影響が支配的となっている．揚力に関しては，物体下 流近傍 $\left(J_{\mathrm{cv}} \sim 50\right)$ では 4.1 節の結果と同じく $L_{\mathrm{cv}}=95$ 付

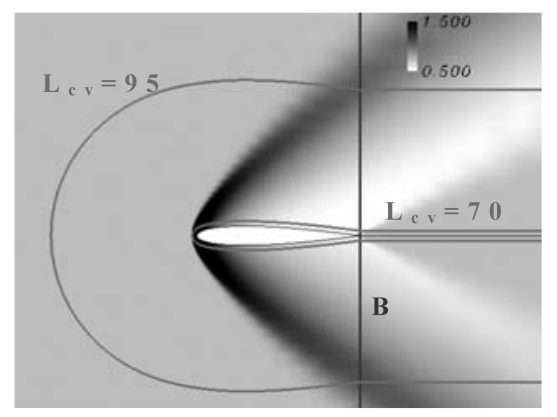

第 8 図 超音速計算における特異積分面位置可視化図
近に大きな差が認められる．また， $J_{\mathrm{cv}}$ の值が小さくなる $\left(S_{\mathrm{J}}\right.$ が物体後方遠方側に移動する) に従って $S_{\mathrm{L}}$ と $S_{\mathrm{J}}$ の 接合部に衝撃波が位置する特異条件の $L_{\mathrm{cv}}$ の值も増加する ため，差の大きな領域がより遠方側に移動していることも 確認できる . 抵抗值に関しても，4.1 節で確認したとおり $S_{\mathrm{L}}$ が前縁上流の離脱衝撃波に接する $L_{\mathrm{cv}}=70$ 付近から， ほぼ前縁上流の衝撃波を包含する $L_{\mathrm{cv}}=100$ 付近の間に大 きな差か認められる . 抵抗值に関する表面積分と CVM と の差の最大值は $60 \mathrm{ct}$ 程度であるが, 前縁上流の衝撃波領 域を避ければ両者は良い一致を見せ, 精度良い抵抗值予測 がなされていることが確認できる．衝撃波領域に関する議 論については 4.3 節で更なる検証を行う .

また，本計算の妥当性の検証として，物体を含まない同 サイズの計算格子上において $M_{\infty}=2.0$ での一樣流計算を 行い, 弚の計算結果に対する CVM の検証も行った . 物体 を含まないので表面積分值は揚・抗力共に 0 として扱える. 兴の $J_{\mathrm{cv}}-L_{\mathrm{cr}}$ 依存性を第 11 図に示した . 揚・抗力值共に外 部境界付近において差が見られるものの, 弚の差は $10^{-13}$ のオーダーであり, 本計算の十分な妥当性か確認できる .

4.3 格子依存性 本節では超音速流れでの CVM によ る空力係数値予測結果に見られた衝撃波による影響を更 に考察するために，弚の格子依存性に関する検証を行う． これまでの $303 \times 131$ の格子 (Original と呼ぶ) に対し， $703 \times 391$ の格子 (翼面上に 601 点, Fine と呼ぶ）を生成 し，超音速条件で計算を行った．CVM の積分面について

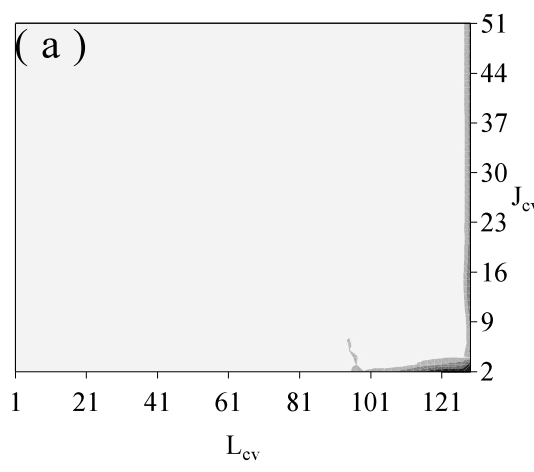

第 9 図 遷音速計算での $J_{\mathrm{cv}}-L_{\mathrm{cv}}$ 依存性

(a) 揚力値について, (b) 抗力值について

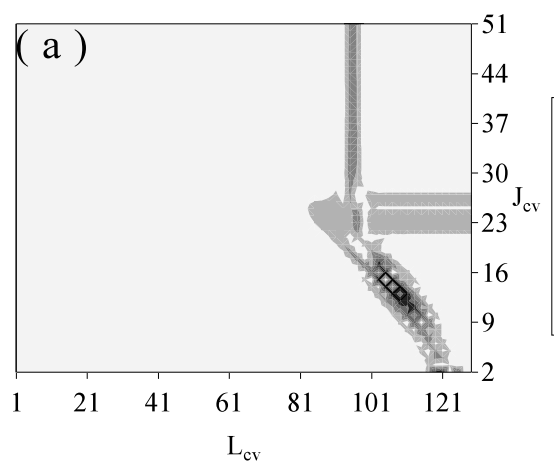

第 10 図 超音速計算での $J_{\mathrm{cv}}-L_{\mathrm{cv}}$ 依存性

(a) 揚力値について, (b) 抗力值について 

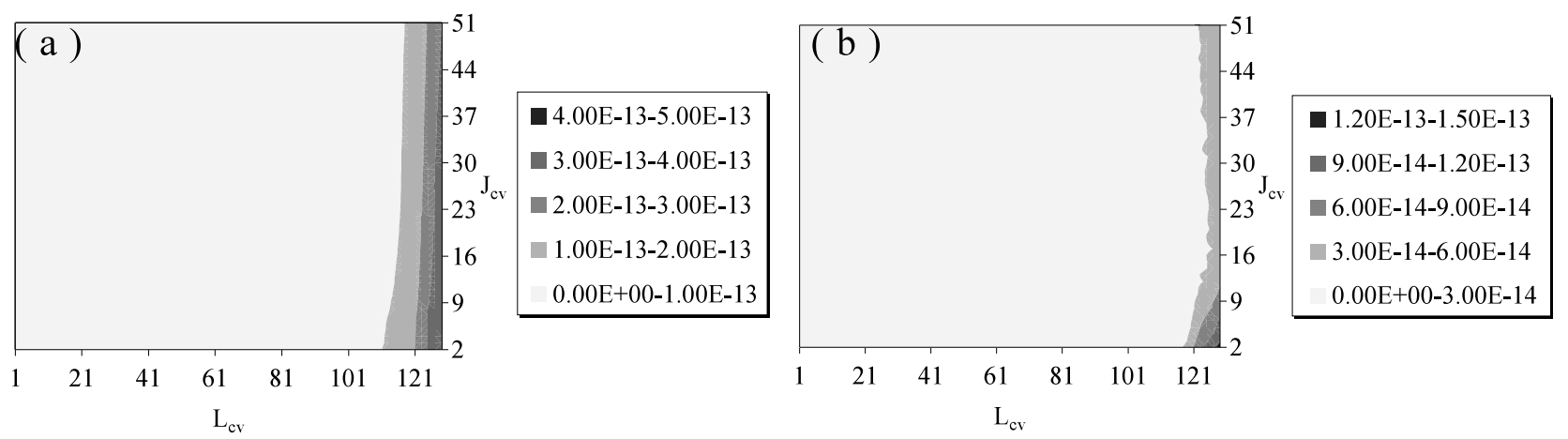

第 11 図 超音速一樣流計算での $J_{\mathrm{Cv}}-L_{\mathrm{cv}}$ 依存性

(a) 揚力値について, (b) 抗力值について

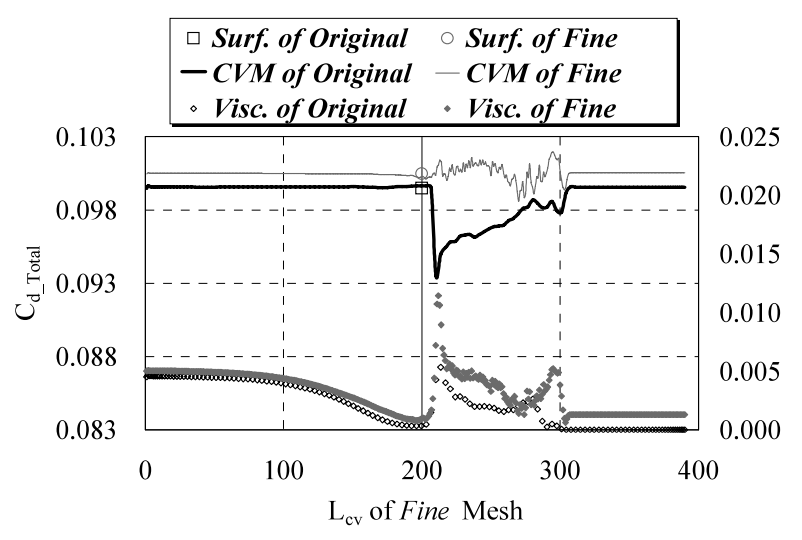

第 12 図格子依存性に関する検証

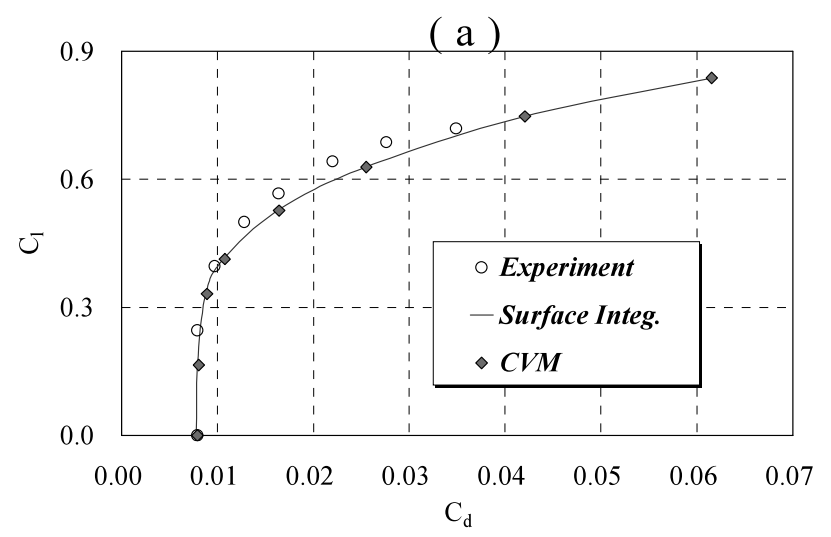

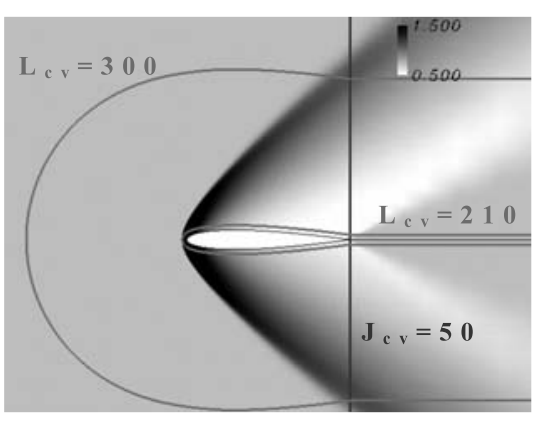

第 13 図 Fine 格子での空間圧力分布図

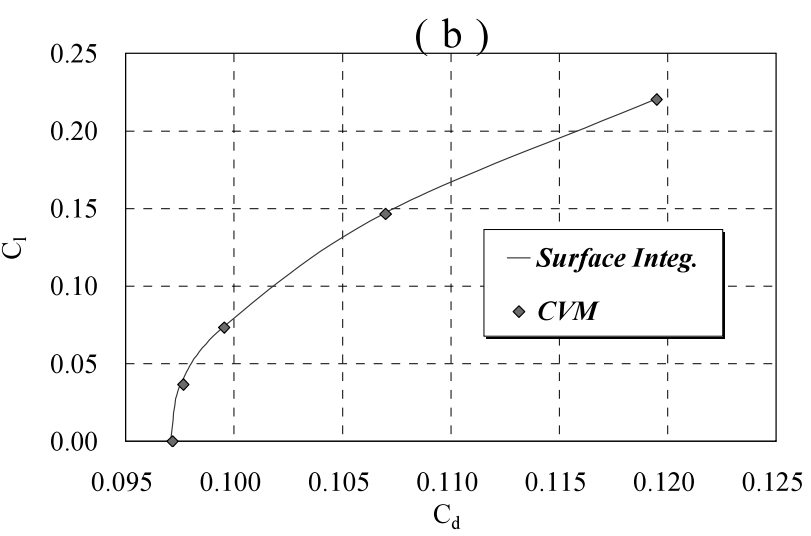

第 14 図 Drag Polar 計算

(a) $M_{\infty}=0.7$, (b) $M_{\infty}=2.0$

は, 前節までの結果から物体下流近傍に設定するのか望まし いと考えられるので， $J_{\mathrm{cv}}=50$ の位置に固定し $L_{\mathrm{cv}}$ に対す る依存性を考察した . 抗力係数值の $L_{\mathrm{cv}}$ 依存性を Original 格子の同条件での計算結果と共に第 12 図に示す .この際， 両格子の座標点を参照し, Original 格子のプロットの横軸 も $L_{\mathrm{cv}}=1 \sim 391$ に対応させて示している. 各表面積分値 も図中央 $\left(L_{\mathrm{cv}}=200\right)$ に示した. 更に CVM の全抵抗値 ( “CVM of ....") 内の粘性項の寄与分を “Visc. of ..." と
して右軸を用い示した . また Fine 格子の圧力分布図と代 表的な $L_{\mathrm{cv}}$ 位置を第 13 図に示した .

Fine 格子による結果においても， $\boldsymbol{S}_{\mathrm{L}}$ が前縁上流の衝撃 波に接する $L_{\mathrm{cv}}=210$ 付近から，ほほ前縁上流の離脱衝撃 波を包含する $L_{\mathrm{cv}}=300$ 付近の間に CVM 抵抗予測值の振 動を確認できる.しかしながら Original 格子に比べ，谷の 粘性項成分がより大きな值を取っており， $S_{\mathrm{L}}$ が前縁上流の 衝撃波に接する際に生じていた強い不連続性は軽減されて 
いることが確認できる．すなわち格子密度の高い格子を用 いることにより，粘性項の効果をより精度良く捉えること ができ，衝撃波付近での CVM 予測精度の改善が成されて いると言える .

4.4 Drag Polar 最後に本節では $M_{\infty}=0.7,2.0$ に おける Original 格子での Drag Polar 計算結果を示す . 積 分面はこれまでの考察から， $J_{\mathrm{cv}}$ に関しては物体下流近傍 に設定すべきと考えられるので $J_{\mathrm{cv}}=50$ に， $L_{\mathrm{cv}}$ は前縁か ら発生する衝撃波を包含し，かつ外部境界の影響を避ける べきであるので $L_{\mathrm{cv}}=120$ とした . 結果を第 14 図に示す . 迎角は $0 \sim 6 \mathrm{deg}$ とし, 遷音速計算においては実験値 ${ }^{13)} も$ 加えて示した。

遷・超音速計算共に，表面積分值との十分な一致が確認 できる. 両ヶース共に, 表面積分值と CVM との差は $2 \mathrm{ct}$ 以内であった . このことから CVM の超音速流れへの十分 な適用性か確認された .

\section{5. 結論}

本研究では NACA0012 翼型周りの 2 次元構造格子計算 を用い, 運動量の流入出の関係を基にした抵抗予測手法で ある CVM の精度検証を行った . 特に , 超音速流れ場への 適用における妥当性について検証を行い，CVM が超音速 流れにも適用できることを示した .

CVM による抵抗値予測においては, Drag Polar 計算に おいて表面積分值との差が総じて 2 ct 以内であり，非常に 良い一致を示した · 超音速流れ場への適用時には，物体遠 方に伝播する強い離脱衝撃波の影響により，積分面の位置 によっては揚・抗力値に強い振動・不連続変動か認められ た . 赍のため，積分面の設定には注意が必要である．しか しながら，格子解像度を高めることにより CVM の粘性項 の計算精度が改善され, 弚の粘性項が振動・不連続性を軽 減することも示された 。

\section{参 考 文 献}

1) Hemsch, M. and Morrison, J.: Statistical Analysis of CFD Solutions from 2nd Drag Prediction Workshop, AIAA Paper 2004-0556, 2004.

2) Kusunose, K.: Advanced Wake Integration Method for Experimental Drag Prediction, von Karman Institute Lecture Series 2003-2, 2003.

3) Brodersen, O., Rakowitz, M., Amant, S., Larrieu, P., Destarac, D. and Sutcliffe, M.: Airbus, ONERA, and DLR Results from the 2nd AIAA Drag Prediction Workshop, AIAA Paper 2004-0391, 2004.

4) Schmitt, V. and Destarac, D.: Recent Progress in Drag Prediction and Reduction for Civil Transport Aircraft at ONERA, AIAA Paper 98-0137, 1998.

5) Paparone, L. and Tognaccini, R.: Computational Fluid Dynamics-Based Drag Prediction and Decomposition, AIAA J., 41 (2003), pp. 1647-1657.

6) Yamazaki, W., Matsushima, K. and Nakahashi, K.: Application of Drag Decomposition Method to CFD Computational Results, AIAA Paper 2005-4723, 2005.

7) Kusunose, K.: A New Concept in the Development of Boomless Supersonic Transport Aircraft, First International Conference on Flow Dynamics, OS5-9, 2004.

8) Matsushima, K., Nakano, T. and Nakahashi, K.: 低ブーム超 音速機形状の逆問題設計，第 17 回計算力学講演会，OS4c-0409, 2004.

9) Murakami, A.: コンピュータによる革新設計技術の飛行実証研 究プログラムについて,「サイレント超音速飛行実現のための実 験・計算融合研究」・レーザー駆動管内加速装置 : 基礎物理の解 明と実用展開」合同シンポジウム，2005.

10) Goto, Y., Obayashi, S. and Kohama, Y.: Drag Characteristics of a Low-Drag Low-Boom Supersonic Formation Flying Concept, AIAA Paper 2005-4604, 2005.

11) Obayashi, S. and Guruswamy, G. P.: Convergence Acceleration of a Navier-Stokes Solver for Efficient Static Aeroelastic Computations, AIAA J., 33 (1995), pp. 1134-1141.

12) Baldwin, B. S. and Lomax, H.: Thin Layer Approximation and Algebraic Model for Separated Turbulent Flows, AIAA Paper 78-257, 1978.

13) Holst, T. L.: Viscous Transonic Airfoil Workshop Compendium of Results, J. Aircraft, 25 (1988), pp. 1073-1087. 